\title{
ESTUDO HISTOLOGICO E HISTOQUÍMICO DO APARELHO EXCRETOR DE GLOSSOSCOLEX PAULISTUS MICHAELSEN, 1926
} (OLIGOCHAETA, GLOSSOSCOLECIDAE)

NELSON BUCK

\section{ABSTRACT}

The present study reveals that the excretory system of Glossoscolex paulistus is formed by open holonephridia (exonephridia). It is noticed that different zones are recognized in the nephridial canal, with defined histological and histochemical characteristics: 1) primary canal; 2) lobed canal; 3) first rounded segment; 4) afferent thin segment; 5) efferent thin segment; 6) second rounded segment; 7) ciliary tube; 8) clear canal; 9) pigmented canal; 10) intermediate canal; 11) bladder; 12) terminal canal; 13) nephridiopore. All these regions are intercellular and cilia are found in regions 1, 2, 3, 6, 7 and 13. The connections between afferent and efferent capillary of the vascular supply of the nephridium are made of capillary loops and dilatations which we call "glomeruli" in this paper. Filtering functions are suggested for the "glomerulus". The response of the lobed canal and the first and second rounded segments to Gomori's reaction is strongly positive and this is found to coincide with the largest concentration of "glomeruli" in the main loops $I$ and II, that suggests a higher filtration capacity for the canal and segments.

\section{INTRODUÇÃO}

Após o estudo da anatomia do aparelho excretor de Glossoscolex paulistus (Buck, 1983) surgiu o interesse de esclarecer alguns aspectos da histologia e histoquímica dos seus nefrídios, com o objetivo de contribuir para o conhecimento da fisiologia nefridial desta Glossoscolecidae.

A maioria dos trabalhos sobre nefrídios de Oligochaeta referem-se a espécies de Lumbricidae: Benham (1891), Maziarsky (1903), Cordier (1934), Goodrich (1945), Graszynski (1963-65). Afora estes, existem informações a respeito de nefrídios de Megascolecidae na série de trabalhos de Bahl (1919-1947).

Quanto à família Glossoscolecidae, existem poucas informações a respeito do aparelho excretor. As principais estão nos estudos de Perrier (1874) em Postoscolex corethrurus; Michaelsen (1897) em Glossodrilus peregrinus e Pickford (1940) em Martiodrilus crassus Rosa, 1895. Todos estes trabalhos apresentam quase que somente o estudo morfológico do aparelho excretor.

Temos notado, porém, que as tendências atuais das pesquisas sobre os nefrídios de Oligochaeta são de abandonar os estudos de anatomia comparativa, para enfatizar descrições puras de ultra-estrutura celular, visando a compreensão de processos físiológicos, como ém Graszynski (1963/65), Koechlin (1970), Vinichenko \& Lebskii (1975), Zerbst-Borofka (1975).

No presente trabalho estudamos a histologia dos nefrídios pré-clitelares, clitelares e pós-clitelares, além de realizar alguns ensaios a respeito de aspectos histoquímicos do canal nefridial. Pesquisamos principalmente fosfotase alcalina, já observada por Dev (1965) em Hirudinaria granulosa (Hirudinea) e por Graszynski (1965) em Lumbricus terrestris.

A ocorrência de bactérias é conhecida de várias espécies de Lumbricidae (Pandazis, 1931) e indicadas por Knop (1929) e Stephenson (1930) em Glossoscolecidae, fato que confirmamos em G. paulistus.

Instituto de Planejamento e Estudos Ambientais, UNESP, Presidente Prudente, SP. 


\section{MATERIAL E MÉTODOS}

Foram utilizados 10 exemplares clitelados de Glossoscolex paulistus obtidos nas proximidades da cidade de Rio Claro, SP (Righi, 1971:48) e mantidos em laboratório conforme Buck (1983:16).

\section{A. Métodos histológicos}

1. Fixação. Os animais foram anestesiados em propilenefenoxetol (Johansen \& Martin, 1965), cortados em pedaços de $5 \mathrm{~cm}$ de comprimento e abertos por uma incisão dorsal, longitudinal e mediana. O material obtido foi colocado na mistura fixadora, pelo tempo necessário. Dependendo do objetivo da preparação utilizamos um dos seguintes fixadores: a) formol 10\%, 24 horas; b) líquido de Bouin acético (Pantin, 1964:9) 24 horas. Após este tempo o material foi transferido para álcool $70 \%$ até o momento de ser utilizado; c) líquido de Gendre (Behmer et al., 1976:31), quatro horas a $4^{\circ} \mathrm{C}$; d) acetona P.A. (Lison, 1960:533) a $4^{\circ} \mathrm{C}$, em três banhos sucessivos de 12 horas cada: em seguida aplicaram-se mais dois banhos de 12 horas à' temperatura ambiente, após o que o material permaneceu na acetona; e) dicromato acético (Bahl, 1919) 18 horas, para preparações totais.

2. Inclusão e microtomia. 'As peças fixadas, exceto as da acetona, foram desidratadas em álcool, diafanizadas em xilol e incluídas em parafina. O material tratado pela acetona foi diafanizado diretamente em benzol e incluído em parafina. Cortes seriados, de 5-7, $\mu \mathrm{m}$ de espessura.

3. Colorações. a) hematoxilina de Ehrlich-eosina (Pantin, 1964:24); b) hematoxilina férrica de Weigert (Langeron, 1934:482); c) tricrômico de Mallory (Pantin, 1964:41); d) Van Gieson (Policard et al., 1957:306); e) digestão pelo KOH (Costa \& Chaves, 1943:212).

\section{B. Métodos histoquímicos}

1. Determinação de carboidratos: a) PAS (McManus, apud Lison, 1960); b) bloqueio pela acetilação (McManus \& Cason, 1950:651); c) acetilação seguida de saponificação (Lison, 1960); d) ação da alfa-amilase seguida de PAS (Lison, 1960); e) reação do "alcian Blue" (Steedman, apud Pearse, 1953:436), $\mathrm{pH} 2,5$.

2. Detecção de enzima: método da fosfatase alcalina segundo Gomori (1952:175).

3. Métodos microbiológicos: reações de Gram e Giemsa (Neder, 1964:39) para a confirmação de bactérias nos nefrídios.

\section{RESULTADOS}

1. Nefrídios pós-clitelares

O holonefrídio típico desta região está representado na figura 1 e é composto de um funil, três alças principais I, II e III e nefridióporo (Buck, 1983, pág. 19).

\section{a. Funil}

O "funil" (Figs. 1-4f) está envolvido externamente pelo epitélio celômico, - qual é constituído por uma camada de células achatadas, com citoplasma ligeiramente acidófilo e núcleos ovóides de cromatina frouxa. Este epitélio repousa sobre uma espessa camada de tecido conjuntivo bem vascularizado, que dá forma e sustentação ao "funil" do nefrídio e prolonga-se pelos lábios superior e inferior do nefróstoma. Neste tecido predomina uma substância fundamental amorfa, que se cora homogeneamente pela técnica do "alcian blue". Em seu interior encontram-se células isoladas, de núcleos mais ou menos arredondados.

A abertura para o celoma, o "nefróstoma", tem um lábio superior (Fig. 3, 1s), formado por uma única camada de células cilíndricas justapostas. A altura destas células diminui do centro para as extremidades do lábio, que são recurvadas para dentro, em forma de ferradura. As células mais altas atingem $9 \mu \mathrm{m}$, enquanto que as mais baixas, das extremidades, alcançam $6 \mu \mathrm{m}$. Sua 
largura é mais ou menos uniforme em toda a extensão do lábio, atingindo cerca de $3 \mu \mathrm{m}$. Toda a superfície livre das células é ciliada e o citoplasma é acidófilo e homogêneo. Seus núcleos fusiformes, de cromatina frouxa e nucléolos bem evidenciados pela hematoxilinia férrica situam-se no terço basal das mesmas. Este epitélio, rico em glicogênio, repousa sobre uma membrana basal PAS positiva.

Aglomerados entre os cílios do lábio superior, encontramos grande quantidade de celomócitos (Figs. 3-4, cel) de forma globosa. O citoplasma dos celomócitos é rico em granulações acidóficas e os núcleos esféricos ocupam posição central. Têm cromatina frouxa e nucléolos bem evidenciados.

O lábio inferior do nefróstoma (Figs. 3 e 4, li) não é ciliado. É formado por um epitélio ligeiramente colunar (fig. 5, epc). Suas células medem $6 \mu \mathrm{m}$ de altura por $4 \mu \mathrm{m}$ de largura, em média, com citoplasma homogêneo e acidófilo. Os núcleos são aproximadamente basais, com cromatina frouxa e geralmente nucléolos fortemente basófilos. Tecido conjuntivo rico em substância intercelular homogênea e células conjuntivas compõe a maior parte do lábio inferior.

A parte mais interna do "funil" é percorrida pelo "canal primário" que é ciliado (Figs. 2-4, cpr) e dirige-se para a alça I. O canal mede aproximadamente $18 \mu \mathrm{m}$ de diâmetro interno e sua cavidade é delimitada por duas séries regulares de células que apresentam reação fortemente positiva para o PAS na região periférica.

Por reconstrução, a partir de cortes transversais e longitudinais, percebe-se que as células parietais do "canal primário" são curvas e em forma de canaleta, com a maior dimensão coincidindo com o eixo longitudinal do canal (Fig. 6). Elas medem cerca de $15 \mu \mathrm{m}$ de comprimento e aproximadamente $5 \mu \mathrm{m}$ de altura. Por vezes, em cortes transversais do canal, as células têm aspecto circular. Seu citoplasma é homogêneo, ligeiramente acidófilo, o núcleo é central e esférico, com cromatina frouxa, e geralmente apresentam dois nucléolos corados fortemente. Na face destas células, voltada para o lume do tubo, percebe-se a região dos grânulos basais dos cílios. Estes se dispõem na cavidade do canal segundo dois tratos opostos, que progridem em uma trajetória helicoidal. O arranjo helicoidal dos cílios é mantido em todos os tratos ciliares do nefrídio e pode ser bem evidenciado apenas em cortes transversais.

Na luz da porção inicial do canal encontram-se, entre os cílios, núcleos fortemente corados que se destacam do conjunto. Estes núcleos têm cromatina frouxa, nucléolos bem evidenciados (Fig. 6, cel) e são semelhantes aos dos celomócitos, porém com as diferentes técnicas empregadas, não foi possível identificar citoplasma ao redor deles. Parecem pertencer a celomócitos que penetram no canal e iniciam um processo de degradação.

A estrutura do "canal primário" é igual tanto na porção pré-septal como na pós-septal. Seu epitélio é envolvido por uma camada conjuntiva de aproximadamente $3 \mu \mathrm{m}$ de espessura, que é a continuação daquela do "funil". Por fora se reconhece o epitélio celômico.

b. Alças I e II

O "canal lobado" (Fig. 7, cl) é o prolongamento do "canal primário" no ramo aferente da alça I e seu diâmetro médio é de $40 \mu \mathrm{m}$. Num mesmo corte transversal ele pode aparecer várias vezes devido às suas voltas e numerosas evaginações laterais. O epitélio que forma o duto neste local, à semeihança do "canal primário" possui dois tratos ciliares, presentes inclusive nas evaginações laterais. As células em forma de canaletas cujos limites foram evidenciados pela reação do PAS, medem cerca de $25 \mu \mathrm{m}$ de comprimento com altura entre 1 e $3 \mu \mathrm{m}$. O citoplasma é homogêneo, acidófilo e rico em glicogêneo, além de apresentar forte positividade para a fosfatase alcalina na zona periférica.

O "canal lobado" dá sequiência ao "primeiro segmento contornado" (Fig. 7, tcI); que tem secção circular mais ou menos regular, com cerca de $50 \mu \mathrm{m}$ de diâmetro. A parede é formada de uma camada de células alongadas, medindo 15 a $20 \mu \mathrm{m}$ de comprimento por 3 a $4 \mu \mathrm{m}$ de altura, também com a 
forma de canaleta, como nos trechos anteriores do duto nefridial. Essas células possuem citoplasma homogêneo e acidófilo, mostrando positividade para o glicogênio e para a fosfatase alcalina. Os núcleos apresentam cromatina frouxa, tendo pelo menos um nucléolo bem visível. O pólo apical das células apresenta dois tratos ciliares, dispostos como nas regiões anteriormente descritas, além das pequenas expansões semelhantes a vilosidades (vi).

Externamente o "primeiro segmento contornado" apresenta uma membrana basal PAS positiva.

A parte seguinte do duto nefridial passa a ser mais fina e aproximadamente retilínea, caracterizando-se o chamado "segmento delgado" (Figs, 2 e 8, sda, sde), situado na alça II. Sua parede é delgada, não apresenta cílios e é formada por células em canaleta, que medem 12 a $18 \mu \mathrm{m}$ de comprimento, com altura em torno de 1,5 $\mu \mathrm{m}$. O citoplasma destas células é homogêneo, com reações para glicogênio e fosfatase alcalina muito mais fracas do que as do "primeiro segmento contornado". Uma membrana basal PAS positiva separa estas células do tecido adjacente. Estas características existem ao longo dos dois ramos do "segmento delgado", que na parte mais próxima da alça II transforma-se, bruscamente, em um tubo de diâmetro maior, chamado anteriormente de "segundo segmento contornado". O "segundo segmento contornado" dispõe-se sinuosamente ao redor do "tubo ciliar", até a extremidade distal da alça II. Sua organização é idêntica à do "primeiro segmento contornado" e também apresenta reações mais fortes para fosfatase alcalina e glicogênio do que as do "segmento delgado".

Seguindo pelo duto nefridial, encontramos, na extremidade distal da alça II, o início do trecho denominado "tubo ciliar" (Figs. 8 e 14, tci), que se caracteriza por ser retilíneo e de diâmetro semelhante ao dos "tubos contornados". Sua parede com espessura aproximada de $2,5 \mu \mathrm{m}$, é formada de células achatadas e de superfície curva, que medem cerca de $20 \mu \mathrm{m}$ de comprimento. Apresentam citoplasma acidófilo homogêneo, rico em glicogênio. Como os segmentos contornados, apresenta ciliação, segundo duas faixas helicoidais, mas a reatividade para a fosfatase alcalina é menor. Os núcleos fusiformes ocupam posição ventral, possuem cromatina frouxa e um nucléolo basófilo. Ao redor deste tubo há um envoltório epitelial constante, que apresenta, no pólo das células voltadas para ele, uma região maiś acidófila. $O$ material acidófilo aparece nos cortes, formando uma "coroa radiada" (Fig. 14 , cr) em torno do tubo, que o identifica à primeira vista. Entre as células epiteliais adjacentes ao "tubo ciliar" e sua parede, existe uma membrana basal PAS positiva.

O duto nefiridial modifica-se novamente ao penetrar no ramo aferente da alça I pela segunda vez. Na região de penetração, o diâmetro do duto aumenta gradativamente até alcançar $60 \mu \mathrm{m}$, ao mesmo tempo que desaparece a ciliação. A parede também se espessa sucessivamente. As células parietais apresentam altura de $10 \mu \mathrm{m}$ e medem até $30 \mu \mathrm{m}$ de comprimento, delimitando uma luz cilíndrica regular. Esta parte do duto nefridial foi chamada "canal claro" (Fig. 8, cc). A forma e disposição de suas células parietais coincidem com aquela já descrita para outras regiões do tubo nefridial. O citoplasma é acidófilo, com organização fibrilar na porção apical e granular em alguns pontos da porção basal, que também apresenta numerosos vacúolos de tamanhos variáveis. As reações para glicogênio e fosfatase alcalina são fracas nestas células. Seus núcleos ovóides apresentam cromatina frouxa e um nucléolo bem visível. Uma membrana PAS positiva separa as células adjacentes das que formam o "canal claro".

Próximo da extremidade distal da alça I, o "canal claro" apresenta um aumento gradativo de diâmetro externo e da espessura parietal, cujo diâmetro externo é o início do "canal pigmentado", atinge em média $75 \mu \mathrm{m}$ e a espessura da parede $18 \mu \mathrm{m}$. As células que compõem a parede são alongadas, medindo até $30 \mu \mathrm{m}$ de comprimento, recurvadas e achatadas no sentido transversal do canal. O citoplasma celular está nitidamente diferenciado em duas regiões (Fig. 9) sendo a apical mais acidófila e granular. Na região basal, as células apresentam grande número de granulações pigmentadas e vacúolos. As granulações, de diferentes tamanhos, apresentam-se incolores ou 
de cor alaranjada, nas preparações coradas pela hematoxilina-eosina. Em preparações coradas pelo método tricrômico de Mallory, as partículas apresentam diferentes tons de vermelho. A reação do PAS é mais forte na região basal das células do canal pigmentado, enquanto existe negatividade para a fosfatase alcalina, em toda sua extensão.

$\mathrm{Na}$ maior extensão do "canal pigmentado" podem-se ver volumosos celomócitos aderentes à parede ou infiltrados entre as células epiteliais que a compõem (Figs. 8 e 11, cel). Os seus limites celulares são bem evidenciados e o citoplasma também é carregado de granulações de pigmento, semelhantes às existentes no interior das células do canal. Da mesma maneira que Cordier (1934:453) descreve em Lumbricus terrestris L. encontramos grande quantidade de celomócitos, carregados de inclusões na superfície da região proximal das alças I e II. Numerosos celomócitos são vistos em diapedese, atravessando a massa nefridial em direção à luz do "canal pigmentado". Sua penetração no canal pigmentado é aparentemente facilitada pelo fino revestimento peritoneal, que os separa da cavidade geral na maior parte de seu percurso. Os celomócitos parecem possuir o nefridiotactismo citado por Cordier (1934:422) em Lumbricus terrestris. Os fragmentos de material pigmentado, vistos na luz do canal, parecem conter restos destas células livres que aí tenham se desintegrado. Celomócitos desprovidos de inclusões e pigmentos não foram observados em nossas preparações desta região do nefrídio.

\section{c. Canal intermediário}

O "canal pigmentado" percorre todo o ramo eferente da alça I e na extremidade distal aumenta bruscamente de diâmetro, passando de 75 para $85 \mu \mathrm{m}$. Sua parede torna-se fina em torno de $10 \mu \mathrm{m}$, enquanto o citoplasma deixa de apresentar a organização anteriormente descrita e torna-se mais homogêneo, "com acidofilia não muito forte. Nesta regiã̉o começam a surgir estruturas em bastonetes, que são típicas da parede do trecho denominado "canal intermediário" (Fig. 12). Estes bastonetes dispõem-se perpendicularmente ao sentido do canal. Eles são formados de fileiras de grânulos de material citoplasmático mais acidófilo, positivos à reação do PAS e levemente positivos à reação da fosfatase alcalina. A acidofilia apresenta-se maior no pólo basal das células, diminuindo em direção ao pólo apical. Os núcleos celulares são centrais, com cromatina frouxa e nucléolos fortemente basófilos,

As células epiteliais que formam o "canal intermediário" são envolvidos por uma fina camada de tecido conjuntivo, no qual percebemos a presença de vasos sangüíneos e alguns núcleos de células conjuntivas. Esta estrutura histológica é uniforme em toda a extensão do "canal intermediário". Superficialmente há uma fina camada de epitélio celômico.

O "canal intermediário" abre-se em uma pequena elevação da parede da alça III, com forma mamelonar, que denominamos anteriormente de "vesícula". Nesta região, a parede do duto, caracterizada pelas estruturas em bastonetes, passa a apresentar mais ou menos bruscamente, um epitélio semelhante ao que reveste a luz da alça III e já apresenta uma fina camada de bactérias.

\section{d. Envoltório das alças I e II}

Os cortes longitudinais e transversais das alças I e II revelam que as diferentes regiốes do duto nefridial são sempre envolvidas por tecido epitelial e conjuntivo. O primeiro é formado pelas próprias células peritoneais que podem ser hipertrofiadas e altas, ou pavimentosas. Por reconstrução de cortes seriados, nota-se que as células hipertrofiadas dispõem-se na superfície das alças como duas faixas helicoidais mais ou menos regulares e podem penetrar entre as diferentes regiões do duto nefridial. Nas regiões onde o epitélio é pavimentoso, predomina tecido conjuntivo preenchendo o espaço entre os túbulos nefridiais (Figs. 8 e 13, ep). As células epiteliais hipertrofiadas apresentam forma cilíndrica, cujo citoplasma, homogêneo na região central e granular na periférica, é acidófilo e com reação positiva para o glicogênio. Seus núcleos são esféricos, centrais, com cromatina frouxa, geralmente com um nucléolo basófilo. As células atingem em média $30 \mu \mathrm{m}$ de altura com largura em torno de $5 \mu \mathrm{m}$. 
O tecido conjuntivo que preenche o espaço entre epitélio e túbulos é rico em substância fundamental, com forte alcianofilia e apresenta-se ricamente vascularizado. Suas células são alongadas, alcançando $15 \mu \mathrm{m}$ de comprimento e $5 \mu \mathrm{m}$ de largura, com citoplasma homogêneo, ligeiramente acidófilo. Os núcleos são ovóides, com cromatina frouxa e nucléolos nem sempre visíveis.

Ao longo das alças I e II, as voltas descritas pelo duto nefridial são separadas por espessura variável de tecido conjuntivo, havendo locais onde as membranas basais entram em contato direto.

$\mathrm{Na}$ superfície dos nefrídios, no interior de seu tecido conjuntivo e entre as células epiteliais hipertrofiadas, há uma densa rede de vasos sanguíneos. As ramificações mais finas dos capilares sanguíneos possuem diâmetro em torno de $3 \mu \mathrm{m}$. Sua parede é constituída de uma delgada membrana endotelial, com aspecto homogêneo. As células endoteliais são alargadas na região mediana, que é ocupada pelo núcleo, e afiladas nas extremidades. Os núcleos, de cromatina frouxa, são ovais e achatados e geralmente acompanham a curvatura dos vasos. Quando visível, o nucléolo é comparativamente menor que o das células epiteliais e conjuntivas anteriormente descritas. As células endoteliais estão assentadas sobre uma membrana basal PAS positiva.

Os capilares sanguíneos estão associados a dilatações, que denominamos "glomérulos" (figs. 15-16, g), estruturas que são mais numerosas nas partes proximais das alças. Os "glomérulos" são em geral esféricos, alguns fusiformes e eventualmente dicotômicos. A dicotomia pode ocorrer em qualquer ponto ao longo das alças nefridiais. Os esféricos têm diâmetro variável de 20 a $30 \mu \mathrm{m}$ e em média $25 \mu \mathrm{m}$. Nos fusiformes os diâmetros máximos longitudinal e transversal variam de $35 \times 20 \mu \mathrm{m}$, a $25 \times 15 \mu \mathrm{m}$. Todos apresentam organização semelhante, como veremos a seguir.

O capilar aferente tem aproximadamente $3 \mu \mathrm{m}$ de diâmetro na entrada do "glomérulo". No interior do mesmo, ele se prolonga como um capilar delgado de cerca de $2,0 \mu \mathrm{m}$ de diâmetro externo e muito enovelado sobre si mesmo. Este continua pelo capilar eferente, com aproximadamente $4 \mu \mathrm{m}$ de diâmetro, que emerge do "glomérulo" em posição oposta ao aferente. O novelo capilar pode ser visto em preparações totais, em que os vasos foram previamente injetados com carmim-gelatina. Nas preparações histológicas ser adas, coradas pela hematoxilina de Weigert-eosina e a partir de material injetado, pudemos seguir o percurso do capilar e reconstruí-lo no espaço (Figs. 17 e 18, g). Nestas preparações, verificamos que a parede do capilar é formada por um endotélio de células bastante achatadas, com núcleos fusiformes fortemente basófilos, medindo $2 \mu \mathrm{m}$ no diâmetro maior. O novelo capilar situa-se no interior de uma cavidade de 20 a $25 \mu \mathrm{m}$ de diâmetro. A parede desta cavidade é formada por um epitélio pavimentoso de células com plasma hialino e núcleos fusiformes. Via de regra se encontra outro revestimento epitelial que corresponde ao peritôneo hipertrofiado, cujas células podem ser separadas em dois tipos quanto à forma: umas cilíndricas, medindo de 15 a $25 \mu \mathrm{m}$ na maior dimensão e outras são mais ou menos cúbicas, medindo de 8 a $10 \mu \mathrm{m}$ de lado. O citoplasma destas células é homogêneo, acidófilo e apresenta reação positiva para o glicogênio. O núcleo das células cilíndricas é fusiforme e excêntrico; o das cúbicas é arredondado e central. Em ambos, a cromatina é frouxa e evidenciamos um nucléolo.

\section{e. Alça III}

A parede da alça III (Fig. 19), apresenta-se revestida externamente pelo epitélio peritoneal pavimentoso com núcleos ligeiramente salientes para a superfície. Sob o epitélio existe fina camada conjuntiva frouxa, rica em substância intercelular de acentuada alcianofilia. Esta contém células, fibras musculares e vasos sanguíneos. A espessura da parede varia ao longo do órgão. É maior na parte proximal da alça onde atinge em média $42 \mu \mathrm{m}$. Na região mediana varia conforme o lado considerado. Atinge $24 \mu \mathrm{m}$ no lado medial, isto é, voltado para a alça I e intestino, e $12 \mu \mathrm{m}$ no lado parietal, ou seja, aquele voltado para a parede do corpo. Na sua extremidade distal, a alça III volta a espessar-se novamente, alcançando $20 \mu \mathrm{m}$. 
Os capilares sanguíneos associam-se a "glomérulos" apenas na parte mais espessa da região proximal da bexiga, alcançando até o $10^{\circ}$ terço do comprimento; nas regiões mais delgadas e na extremidade distal, os "glomérulos" são substituídos por alças capilares (Fig. 20).

A disposição da musculatura na parede da alça III pode ser observada em material parcialmente digerido pelo $\mathrm{KOH}$. Verificamos que a musculatura compõe-se de numerosas faixas, cujas larguras variam de 20 a $30 \mu \mathrm{m}$ (Fig. $21, \mathrm{fm})$ e que se dispõem num sentido helicoidal ao longo do eixo maior da bexiga. Em pontos irregulares, as faixas ramificam-se dicotomicamente. Em cada bifurcação, uma das faixas resultantes continua na mesma direção da original e a outra segue em direção oposta. Estas últimas passam sob, e por vezes sobre, as demais, resultando um aspecto entrecruzado. $O$ entrecruzamento resulta também do fato de as fibras helicoidais contornarem duas vezes a alça, como se observa facilmente nas extremidades do órgão.

Uma membrana PAS positiva separa a camada conjuntiva do epitélio interno, que reveste a luz da alça III. Este epitélio é formado por uma única camada de células facilmente observável na maior extensão da parede, com exceção das duas extremidades, onde ele tem aspecto sincicial e a parede é mais espessa. Os limites celulares nestas regiões são de difícil observação; porém, foram visualizados com a técnica do PAS caracterizando-se um epitélio pluriestratificado, com número variável de estratos nucleares, entre dois e quatro, no máximo.

O epitélio apresenta, no pólo apical das células, uma espessa camada de estruturas em bastonetes, fortemente basófila, com altura entre 2 e $3 \mu \mathrm{m}$ e correspondem a bactérias, lembrando o que ocorre em Hirudinea (Avel, 1969: 529).

$\mathrm{Na}$ extremidade proximal, onde se abre o "canal intermediário", ocorre - maior número de camadas nucleares. Elas diminuem gradativamente em direção à parte mediana da alça III, passando a um único estrato de células mais ou menos cilíndricas (Fig. 19, epi). As características citoplasmáticas do epitélio mantêm-se em toda sua extensão. No interior das células observam-se massas basófilas, que as preenchem quase totalmente. O núcleo, quando visível, é esférico, apical, apresentando cromatina reticular e nucléolo fortemente basófilo.

A superfície interna da alça III apresenta saliências e reentrâncias, que são mais acentuadas na região proximal do órgão. A irregularidade superficial diminui, gradativamente, em direção à extremidade distal da alça III, que tem uma superfície interna aproximadamente lisa. Neste mesmo sentido diminui a espessura da camada bacteriana, que pode mesmo faltar em alguns pontos.

\section{f. Canal terminal}

É um tubo curto, de forma cônica, afunilando-se na direção do "nefridióporo". Seu comprimento médio é de $300 \mu \mathrm{m}$ sem contar a parte intraparietal e o diâmetro varia com o estado de distensão. A estrutura histológica é semelhante à da parede da bexiga. O epitélio de revestimento interno apresenta células sucessivamente com menor superfície, na dirção do "nefridióporo" (Fig. 22, epi). O citoplasma é homogêneo, ligeiramente acidófilo e na superfície livre das células, bactérias podem ser vistas em pequeno número. Os núcleos celulares são ovóides, com cromatina frouxa e nucléolo basófilo. Todo o epitélio está assentado sobre uma membrana basal PAS positiva. Sob ela, encontra-se uma fina lâmina conjuntiva com predominância de substância intercelular homogênea, contendo uma camada de fibras musculares e capilares sanguíneos. Um pequeno número de núcleos de células conjuntivas pode ser visto. Externamente existe revestimento peritoneal até o ponto em que penetra na parede músculo-dermática do corpo.

A parede intraparietal do "canal terminal" atinge $400 \mu \mathrm{m}$ de comprimento em média e abre-se na superfície pelo "nefridióporo". Até penetrar na parede, encontram-se células alongadas, revestindo a luz do canal, com as características citoplasmáticas e nucleares já descritas. Imediatamente após penetrar na parede, as células alongadas são bruscamente substituídas por cé- 
lulas aproximadamente cúbicas (Fig. 22). Seu citoplasma é homogêneo, acidófilo e o núcleo central, esférico, com cromatina frouxa, apresenta um nucléolo visível. Progredindo para o exterior, estas células tornam-se gradativamente mais altas, cilíndricas e ciliadas. Este trecho corresponde à metade ental, intraparietal do duto, que apresenta uma luz mais larga do que na metade ectal. Mede em média $70 \mu \mathrm{m}$ de diâmetro externo. A passagem da parte mais larga ental, para a mais estreita ectal, é brusca. Uma camada de bactérias, semelhante à que existe na alça III, reveste o epitélio, até o ponto onde se inicia a transição entre células alongadas e cúbicas.

$\mathrm{O}$ epitélio cilíndrico ciliado mede $25 \mu \mathrm{m}$ de altura e a largura de suas células é de aproximadamente $8 \mu \mathrm{m}$. O citoplasma celular é homogêneo, mais acidófilo e rico em glicogênio do que o epitélio da porção ectal do canal do "nefridióporo". Os núcleos têm posição basal, são fortemente corados e apresentam cromatina frouxa e nucléolos bem visíveis.

A parte ectal intraparietal tem diâmetro externo variando em torno de $50 \mu \mathrm{m}$. É formada por um epitélio cúbico com cerca de $15 \mu \mathrm{m}$ de altura, cujas células de aspecto bastante uniforme não são ciliadas. O seu citoplasma é pouco acidófilo, estruturado em fibrilas que se coram de forma homogênea. Os núcleos são centrais, com cromatina frouxa e nucléolo fortemente basófilo. Este epitélio é contínuo com a epiderme, razão pela qual sua pigmentação típica já pode ser vista no pólo apical das células do terço ectal do duto. Também podem-se encontrar mucócitos do tipo comum na epiderme, entre as células epiteliais desta região. $\mathrm{Na}$ maior porção do terço final do duto, percebe-se a presença da cutícula que se espessa à medida que progride para o exterior, até atingir a espessura típica da superfície do corpo. Tanto o epitélio cúbico, como o cilíndrico, estão assentados sobre uma membrana basal PAS positiva, que os separa da musculatura parietal.

No trecho intraparietal do canal terminal, apõe-se na sua face anterior uma grande massa muscular (Fig. 22, ml) com forma cônica, cujo ápice se salienta na cavidade do corpo. Esta massa apresenta o diâmetro da base em torno de $160 \mu \mathrm{m}$ e de altura aproximadamente $320 \mu \mathrm{m}$. Este cone muscular tem a base voltada para a epiderme e pertence à camada longitudinal dos músculos parietais. Suas fibras estão presas de um lado à membrana basal do duto e do outro continuam pela musculatura longitudinal da parede do corpo. Algumas fibras que aparecem no corte da musculatura pertencem ao conjunto de fibras musculares que movimenta as cerdas.

\section{Nefrídios clitelares e pré-clitelares}

a. Funil e alças I e II

O "funil" e as duas primeiras alças destes nefrídios podem mostrar nítidas diferenças externas, quando comparados com os pós-clitelares. Contudo, suas características histológicas e algumas propriedades histoquímicas por nós verificadas são essencialmente as mesmas, com pequenas diferenças.

Nos cortes transversais (Fig. 23) vê-se que as alças têm contorno circular, como nos nefrídios pós-clitelares, nos segmentos XI a XXIII. Porém as secções do tubo nefridial são em geral irregularmente achatadas e não mais circulares, como na região pós-clitelar. O contorno irregular dos tubos é mais acentuado nos nefrídios do segmento $\mathrm{X}$ e anteriores a ele, nos quais o próprio contorno das alças é irregular. Ainda nestes nefrídios a parede do "canal pigmentado" é mais fina, atingindo em média $12 \mu \mathrm{m}$, e apresenta menor quantidade de inclusões citoplasmáticas que nos demais.

\section{b. Envoltório das alças I e II}

A massa tissular que envolve os dutos nefridiais nas alças I e II é mais desenvolvida que nos nefrídios pós-clitelares. O espaço entre os túbulos apresenta grande número de células epiteliais hipertrofiadas (Figs. 23-24, ep), que medem cerca de $20 \mu \mathrm{m}$ de altura por aproximadamente $8 \mu \mathrm{m}$ de largura, em média. O citoplasma é homogêneo com fraca acidofilia. Os núcleos, de posição central, apresentam cromatina frouxa, com um só nucléolo visível. Entre 
os grupos de células epiteliais há tecido conjuntivo alcionófilo, com células fusiformes que medem $15 \times 15 \mu \mathrm{m}$ nos maiores diâmetros, com citoplasma homogêneo e acidófilo. Seus núcleos são esféricos, de posição central, com cromatina frouxa e um nucléolo visível basófilo. Numerosos núcleos são vistos espalhados pela substância intercelular, mas não foi possível visualizar os limites de todas as células conjuntivas em um corte. Ocorre grande quantidade de alças capilares na massa conjuntiva e entre as células epiteliais. Interessante notar a total ausência de "glomérulos" no sistema capilar dos nefrídios, a partir do segmento X para frente.

\section{c. Alça III}

A organização histológica da alça III dos nefrídios clitelares e pré-clitelares é praticamente a mesma que a dos pós-clitelares, porém sua parede é mais espessa e apresenta saliências e reentrâncias mais acentuadas na superfície interna (Fig. 25). Quanto ao arranjo da musculatura, mantém-se com suas fibras dispostas de modo a formar de duas até quatro espirais contínuas, semelhantes à já descrita. A espessura da camada muscular (Fig. 25) é consideravelmente maior que nos nefrídios pós-clitelares e atinge em média 20 um. As células epiteliais que revestem a luz são achatadas, medindo aproximadamente $40 \mu \mathrm{m}$ de largura por $10 \mu \mathrm{m}$ de altura e estão assentadas sobre uma membrana basal PAS positiva. O pólo apical destas células apresenta uma membrana dobrada, com uma camada de bactérias na sua face externa. Seu citoplasma é acidófilo, homogêneo e freqüentemente contém bactérias. Os núcleos celulares possuem cromatina reticular e um nucléolo visível.

A espessura da parede da alça III dos nefrídios clitelares e pré-clitelares varia como nos pós-clitelares. Como nestes, as partes mais espessas são pluriestratificadas, mantendo as mesmas características descritas anteriormente. Nas reentrâncias observam-se massas volumosas de bactérias, além de aglomerados na luz do órgão.

Não é possível reconhecer-se, em preparações totais dos nefrídios do segmento XX para a frente, o limite entre a bexiga e o "canal terminal". Em preparações histológicas vê-se que o canal diferencia-se como um estreitamento sucessivo da bexiga. Os mesmos estratos tissulares são conservados, porém com elementos componentes algo diferentes, que se modificam gradualmente de um para outro.

O revestimento interno do canal terminal (Fig. 26, epi) é feito por células cilíndricas com altura em torno de $40 \mu \mathrm{m}$ e largura de até $15 \mu \mathrm{m}$, com limites celulares bem nítidos. É um epitélio pseudoestratificado, cujas células apresentam, na porção apical, citoplasma com vacúolos mais claros e em sua parte basal, acúmulo de grânulos basófilos. Algumas células apresentam um único grânulo basófilo volumoso. O citoplasma é fracamente acidófilo, apresentando-se quase incolor nas diferentes técnicas empregadas. Os núcleos são visíveis nas preparações férricas de hematoxilina e apresentam cromatina frou$\mathrm{xa}$, com nucléolos bem corados. Entre as pequenas reentrâncias delimitadas pelas células do epitélio interno e na sua superfície, ocorre uma camada de bactérias. Estas são bastonetes de até $3 \mu \mathrm{m}$ de altura, que à primeira vista parecem constituir uma camada de cílios.

$\mathrm{Na}$ região de transição entre a parte vesiculosa da alça III e o "canal terminal", observa-se que o epitélio aproximadamente cúbico existente na parede da mesma é aos poucos substituído pelo epitélio cilíndrico, com o alongamento gradativo das células epiteliais e conseqüiente estreitamento da luz do órgão.

A camada de músculo da parede do canal é mais espessa do que a da bexiga, medindo até $25 \mu \mathrm{m}$ de espessura, e é envolvida por fina capa de tecido conjuntivo que penetra entre as faixas musculares e é percorrida por inúmeras alças capilares. Separando o epitélio interno da camada conjuntiva, observa-se uma membrana basal PAS positiva. Externamente o tubo muscular é revestido pelo epitélio celômico, que forma uma fina membrana. A porção intraparietal deste canal tem organização semelhante à dos nefrídios pós-clitelares. 


\section{DISCUSSĀO}

Os órgãos excretores de Glossoscolex paulistus variam anatomicamente (Buck, 1983), porém sua histologia e histoquímica se apresentam bastante uniformes, ao longo do corpo.

O "funil", parte inicial do nefrídio, apresenta organização que lembra a de Lumbricus terrestris. Nesta Lumbricidae, segundo Benham (1891-295, pl. XXIII, figs. 4 e 7), Rosen (1911:138) e Goodrich (1933:166), existe uma única grande célula, denominada "célula central", ocupando a região de transição entre o espaço interlabial e o início do canal primário. Estes autores afirmam que todo o canal primário, como a maior extensão do duto nefridial são intracelulares. Apenas a alça III é considerada de organização intercelular. Tal organização também é descrita por Maziarski (1903:71) e Cordier (1934:439) na mesma espécie. A organização intracelular do duto é admitida em Allolobophora caliginosa (El Duweini, 1940), Pheretima posthuma (Bahl, 1919), Lampito mauritii (Bahl, 1924), e Hopholchaetella khandalensis (Bahl, 1942).

Vanderbrock (1934:19) e Graszynski (1963:209), estudando Lumbricus terrestris, sugerem que o canal nefridial é intercelular no pescoço do "funil" e algumas partes das alças I e II, como "tubo ciliar médio" e "tubo estreito", sem contudo precisar a região. Estes autores também descrevem a existência de uma "célula central" na abertura do "nefróstoma".

Em nosso material não existe uma "célula central" perfurada no início do canal. Verificamos que o epitélio dos lábios contacta diretamente com as células em canaleta do duto ciliar ("canal primário"). A transição é, portanto, intercelular. As pesquisas de Graszynski (1963:209) sobre ultraestrutura do nefrídio de $L$. terrestris descrevem o duto nefridial como formado por células em canaleta, ligadas por "células de fronteira".

A técnica histoquímica do PAS utilizada por nós permitiu evidenciar os limites celulares ao longo das diferentes regiões do duto nefridial de $G$. paulistus. Assim, pudemos verificar que se trata de um tubo de organização intercelular, diferindo neste aspecto daquele de Lumbricus terrestris, cujo funil, apesar de ser o mais estudado, ainda apresenta organização controvertida.

A porção seguinte do duto nefridial é o "canal lobado" que apresenta características histológicas e histoquímicas peculiares: o pólo apical das células de sua parede possui vilosidades e cílios, um citoplasma rico em glicogênio e fortemente Gomori-positivo.

O "canal claro" de luz mais larga é Gomori-negativo, não ciliado, sem vilosidades e suas células dão reação mais fraca para o glicogênio, conjunto de características que sugerem uma área de menor atividade de reabsorção, quando comparada com a primeira. Este canal é sucedido pelo "canal pigmentado" situado no ramo eferente da alça I. Neste trecho verificamos um acúmulo de grânulos pigmentados, semelhante ao que ocorre no chamado "segmento ciliar" da alça II dos nefrídios de Lumbricus terrestris (Cordier, 1934:464), no "tubo ciliado castanho" dos nefrídios septais de Pheretima posthuma (Bahl, 1919:86), Lampito mauritii (Bahl, 1924:79) Tonoscolex (Bahl, 1941:456), Eutiphoeus foveatus e Hoplochaetella bifoveata (Bahl, 1942:433 e 444).

A organização da parede do "canal intermediário" apresenta estruturas em bastonetes, semelhantes àquelas descritas por Cordier (1934:443) em Lumbricus terrestris, nas partes por ele chamadas de "primeiro e segundo segmentos com bastonetes", das alças I e II. Segundo o autor, estas estruturas estariam relacionadas com a sustentação e reabsorção de água nos nefrídios. Notamos que ocorre um grande aumento da área com bastonetes nos nefrídios clitelares e pré-clitelares, em comparação com os posteriores, devido ao alongamento do "canal intermediário". Talvez possa ocorrer nestes órgãos uma relação entre as estruturas em bastonetes e economia de água. Histoquimicamente as estruturas com formas de bastonetes correspondem a zonas mais acidófilas do citoplasma, ricas em glicogênio e ligeiramente positivas para a reação de Gomori. Destas características pode-se deduzir uma função de reabsorção para esta parte do nefrídio. 

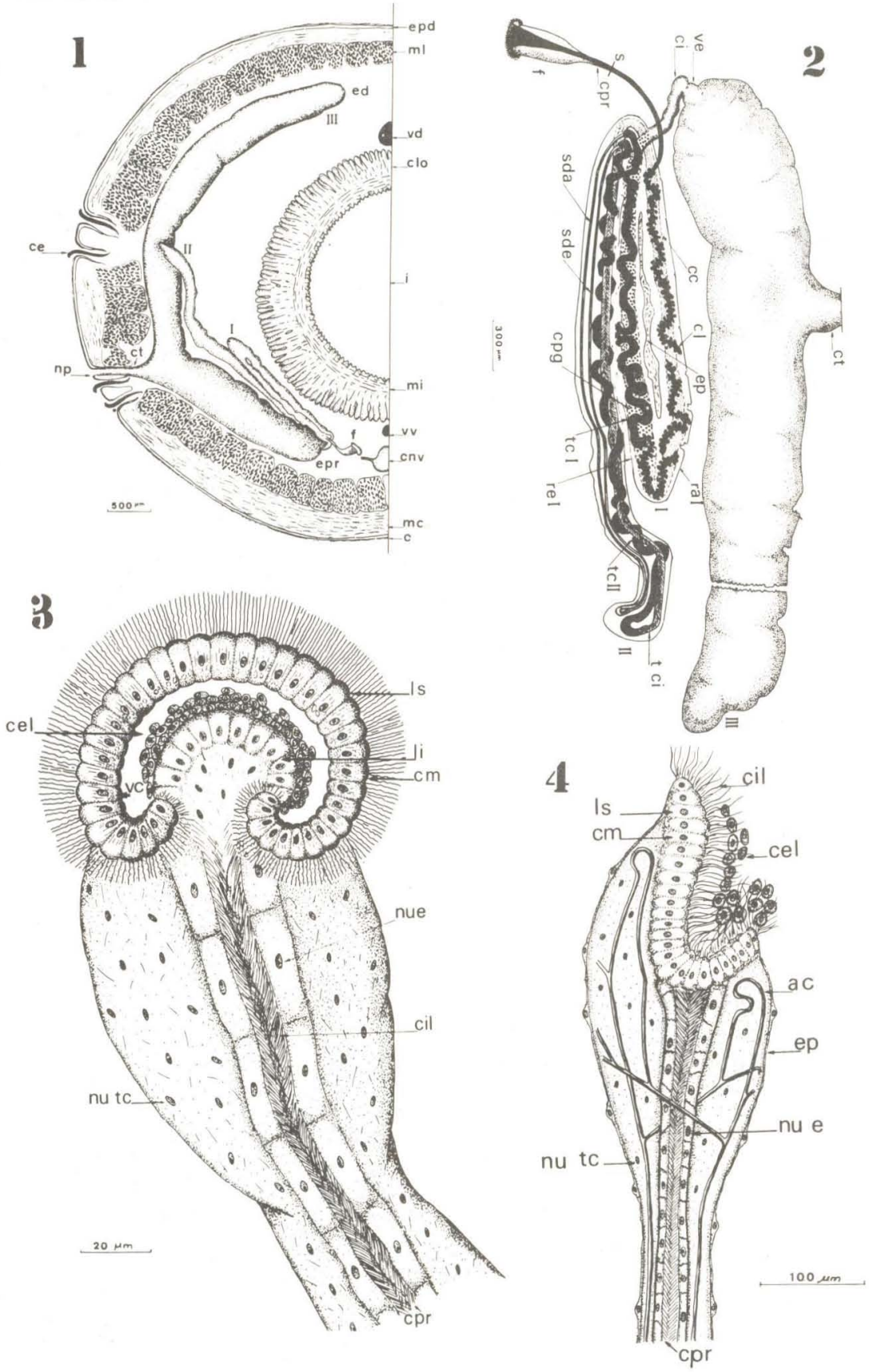

Glossoscolex paulistus: 1, corte transversal, mostrando a situação topográfica do nefrídio (montagem semi-esquemática; o septo e o envoltório peritoneal não representados); 2, preparação total do nefrídio da região pós-clitelar (técnica da fosfatase alcalina de Gomori); 3, funil de nefrídio da região pós-clitelar, vista ventral; 4, idem, perfil (preparação total de material injetado com carmim-gelatina de McLung) (Figs. 3-4 - Detalhes observados por transparência). 

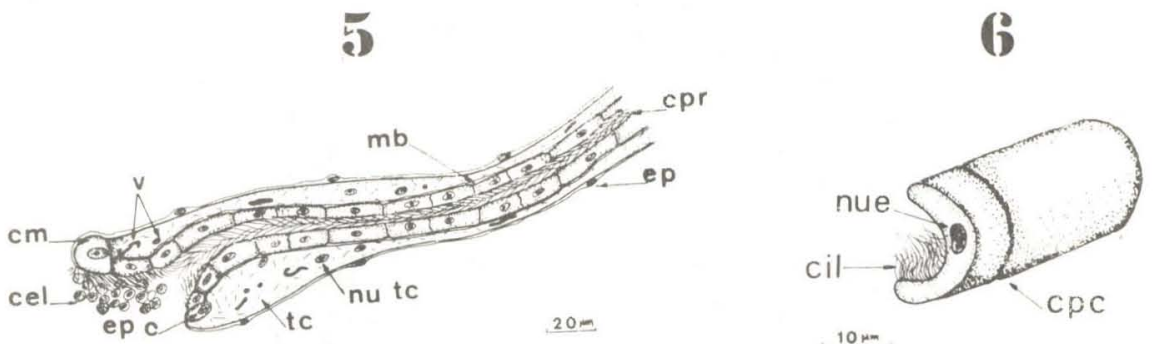

$10 \mu \mathrm{m}$
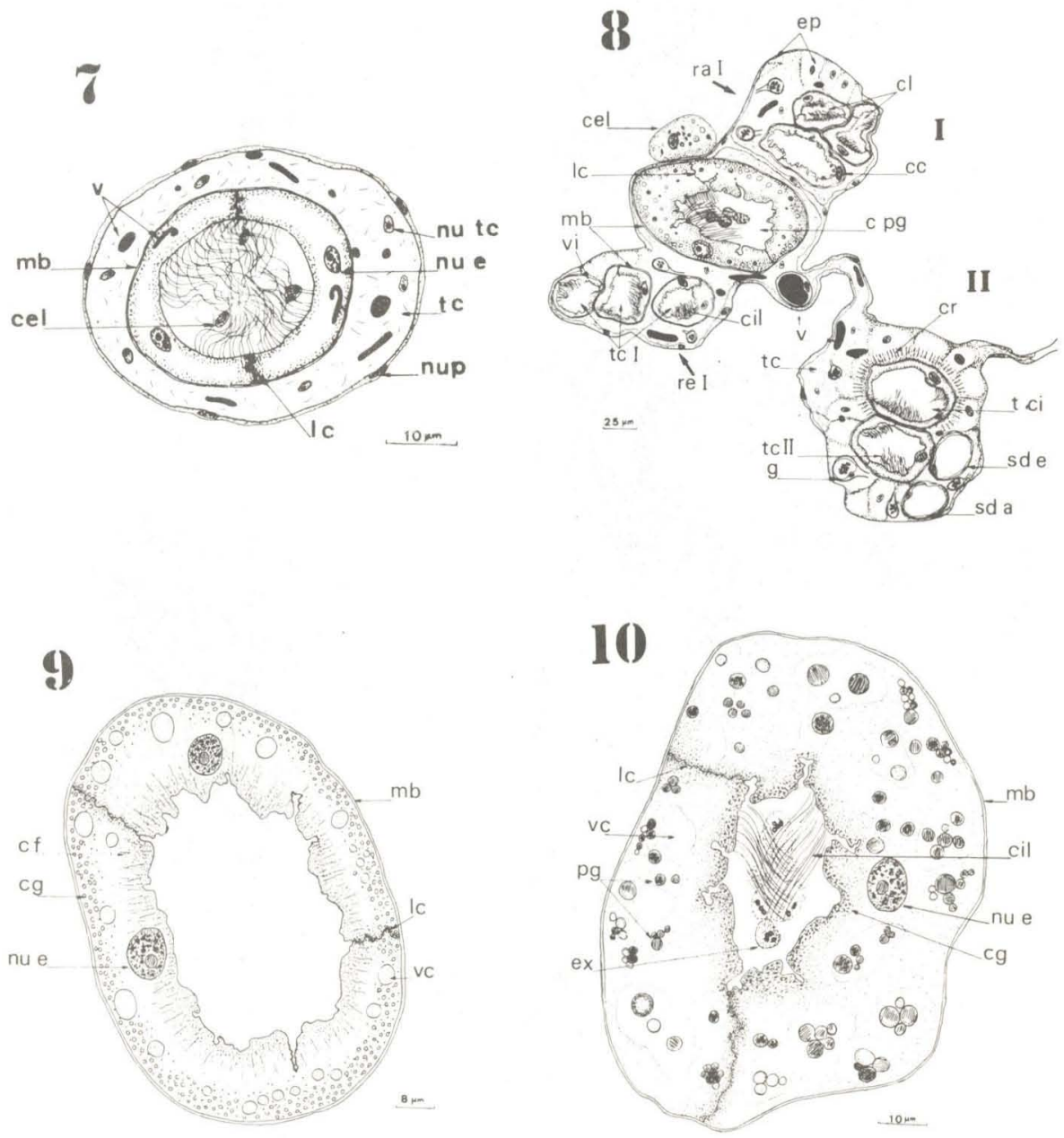

Glossoscolex paulistus: 5, funil de nefrídio pós-clitelar, corte longitudinal; 6 . esquema ideal de célula da parede do canal nefridial; 7 , canal primário à altura do septo, corte transversal; 8, alças I e II, corte transversal e nefrídios pós-clitelares; 9, canal claro, corte transversal, nefrídios pós-clitelares; 10, corte transversal do canal pigmentado, nefrídios pós-clitelares. 


\section{1}
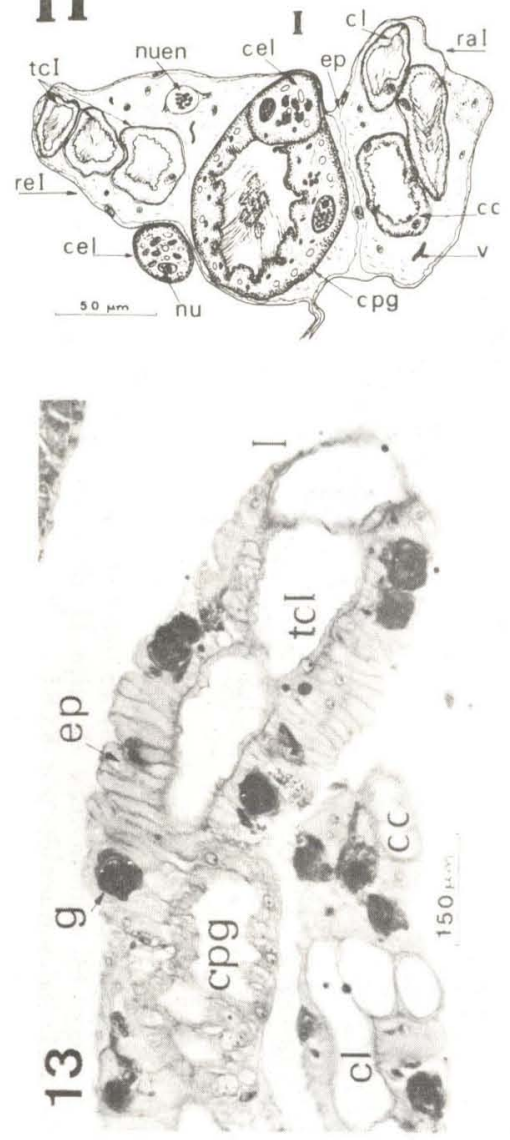

12

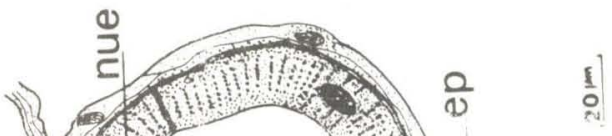

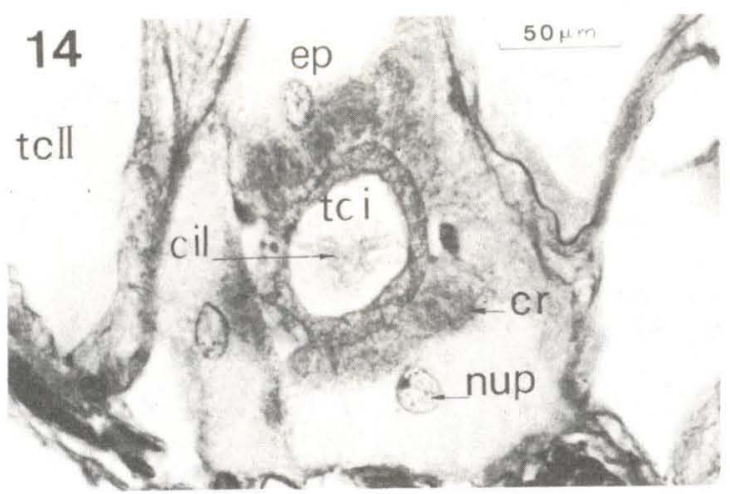

Glossoscolex paulistus: 11, alças I e II, corte transversal, com celomócito e diapedese na parede do canal pigmentado; 12 , corte transversal do canal i, termediário, nefrídio pós-clitelar; 13, corte longitudinal da alça I de nefrídi pós-clitelar; 14, corte transversal do tubo ciliar de nefrídio pós-clitelar. 

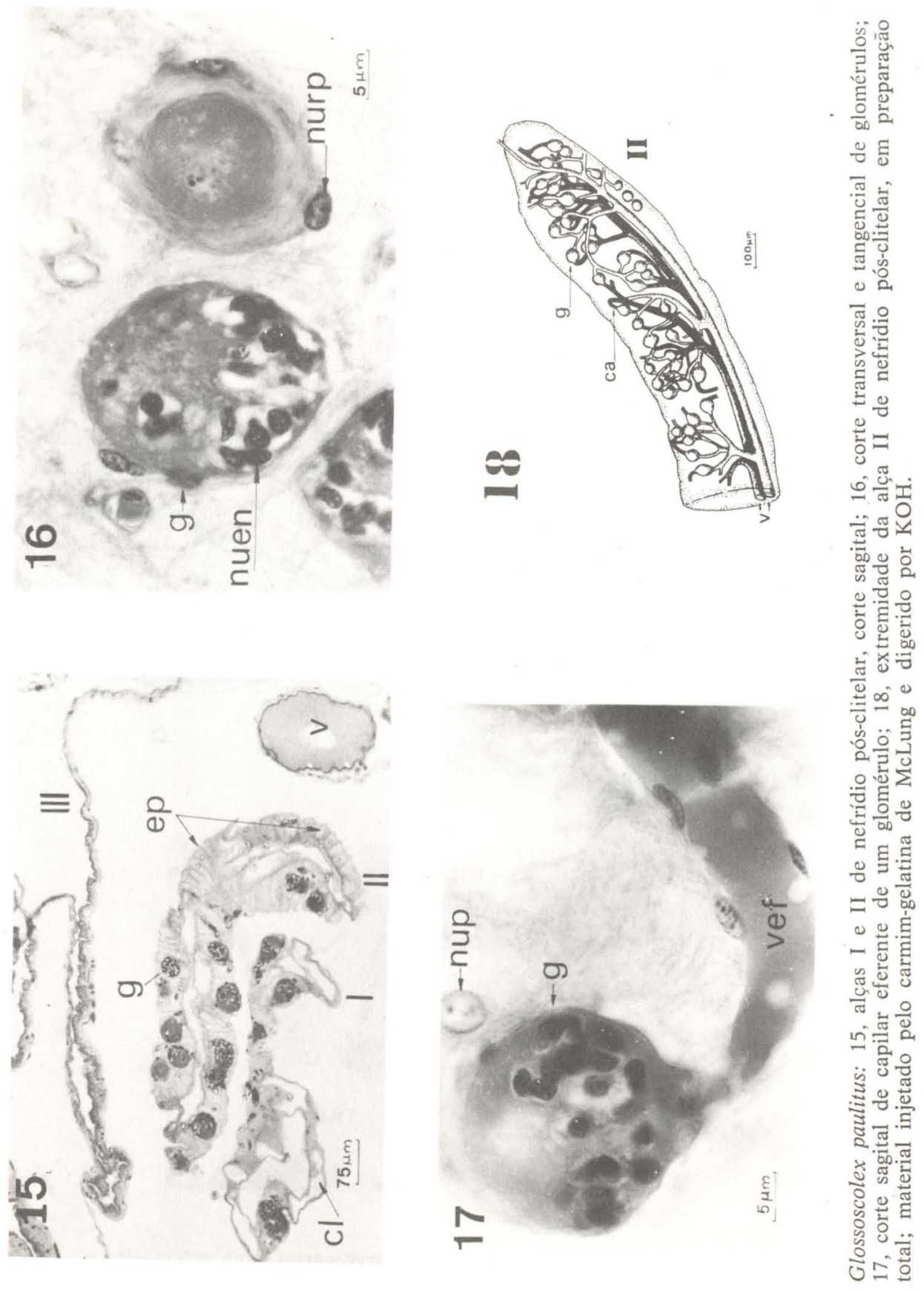

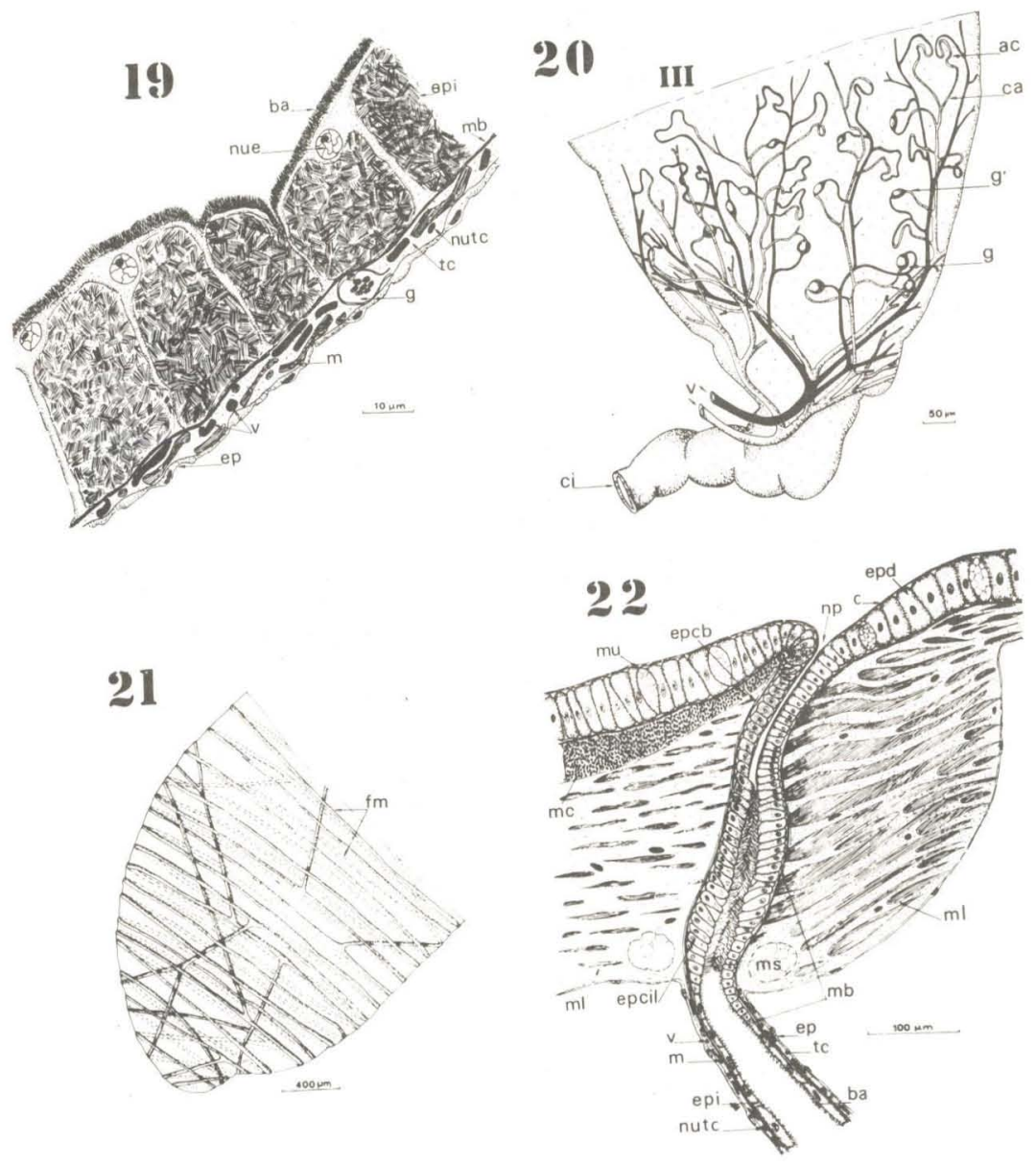

Glossoscolex paulistus: 19, corte transversal da parede da alça II de nefríd:o pós-clitelar; altura do terço proximal do órgão; 20 , fragmento da região proximal da alça III de nefrídio pós-clitelar; 21, esquema do arranjo das fibras musculares na parede da alça II de nefrídio pós-clitelar. 

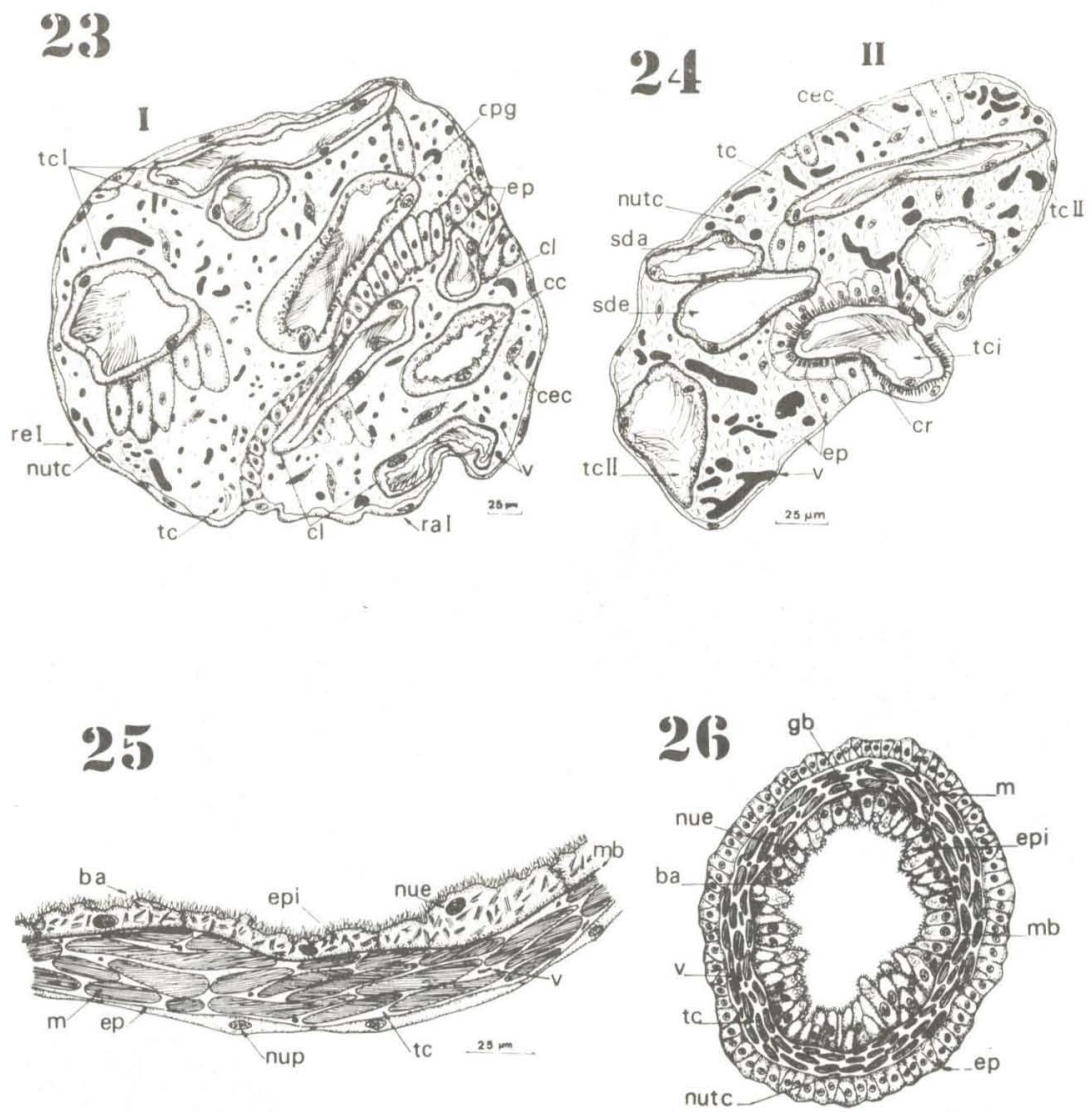

$28 \mathrm{\mu m}$

Glossoscolex paulistus: 23, corte transversal da região média da alça I de nefrídio pré-clitelar; 24 , corte sagital, pouco oblíquo, da alça II de nefrídio pré-clitelar; 25, corte transversal da parede da alça III de nefrídio pré-clitelar; 26 , corte transversal do canal terminal de nefrídio clitelar.

Quanto à bexiga, pode-se notar apenas que suas paredes aumentam de espessura com a cefalização. O fato deve estar relacionado com a maior atividade muscular característica da região anterior do animal. No local, as bexigas devem estar sujeitas a maiores pressões externas. Além disso, o longo "canal terminal" (Buck, 1983, 25) que ocorre nos nefrídios clitelares e préclitelares deve exigir maior esforço muscular para a eliminação da urina. Sabe-se que em Lumbricidae a urina acumula-se por dois a três dias (Laverack, 1963).

A abertura de cada nefrídio para o exterior é feita por um nefridióporo, que diverge histologicamente daqueles descritos em Lumbricus terrestris (Benham, 1891; Maziarski, 1903), Pontoscolex corethrurus (Bahl, 1944) e Allolobophora caliginosa (El Duweini, 1940). O nefridióporo de Glossoscolex paulistus é precedido de um canal ciliado na sua metade ectal que falta naquelas espécies e ainda, ao contrário delas, não apresenta um esfíncter, como observou Ljungstrom (1972:200) em Glossoscolex uruguyaensis. A massa muscular pertencente à parede do corpo, que tangencia o canal, talvez possa funcionar como uma válvula, por compressão. 
$\mathrm{Na}$ rede sanguínea dos nefrídios, os "glomérulos" apresentam o diâmetro do capilar aferente menor do que o do capilar eferente e eles se unem por um novelo capilar ainda mais fino. Isto sugere um mecanismo de filtração semelhante ao de Chordata. Porém, se tal ocorre, o material filtrado não deve passar diretamente ao duto nefridial, devido à posição dos "glomérulos" e seus envoltórios.

A ocorrência de bactérias nos nefrídios de Oligochaeta Lumbricidae foi constatada por vários pesquisadores como Maziarski (1908), Knop (1926), Pandazis (1931) e Scott \& Musgrave (1973). Eles indicam bactérias em forma de bastonetes na "ampola", "Drusenkanal", "wide tube" = "canal claro" e na bexiga. Glossoscolex paulistus não tem ampola nos nefrídios e bactérias foram detectadas apenas na bexiga, tanto na cavidade como no interior das células parietais. Nos cortes e esfregaços encontramos apenas bacilos Gram-negativos, de coloração uniforme.

\section{BIBLIOGRAFIA}

Avel, M., 1959. Classe des annélides oligochètes. In: Grassé, P. Traité de Zoologie. Paris, Masson, v. 5, fasc. 1. p. 224-593.

Bahl, K. N., 1919. On a new type of nephridia found in Indian earthworms of the genus Pheretima. Q. Jl. microsc. Sci. 64: 67-117.

Bahl, K. N., 1924. Enteronephric type of nephridial system in Lampito. Q. $J l$. microsc. Sci., 68: 67-69.

Bahl, K. N., 1941. The enteronephric type of nephridial system in genus Tonoscolex (Gates). Q. Jl. microsc. Sci., 82: 443-66.

Bahl, K. N., 1942. Studies on the structure, development and physiology of the nephridia of Oligochaeta. Part I: General introduction, and the nephridia of the Sub-family Octochetinae. Part II: Multiple funnels of the nephridia. Q. Jl. microsc. Sci., 83: 423-57.

Bahl, K. N., 1944. Studies on the structure, development, and physiology of the nephridia of Oligochaeta. Part III. The branching and division of nephridia, and Eisen's so-called "safety valves" in Pontoscolex. Q. $\mathrm{Jl}$. microsc. Sci., 84: 1-17.

Bahl, K. N., 1947. Excretion in the Oligochaeta. Biol. Rev. of Cambridge Philos. Society., 22: 109-47.

Behmer, O. A., E. M. C. Tolosa \& A. G. Freitas Neto, 1976. Manual de Técnicas para Histologia Normal e Patológica. São Paulo, Edart. 251 p.

Benham, W. B., 1891. The nephridium of Lumbricus and its blood-supply: with remarcks on the nephridia of other Chaetopoda. Q. Jl. microsc. Sci., n.s., 32: 293-334.

Buck, N., 1983. Anatomia do aparelho excretor de Glossoscolex paulistus Michaelsen, 1926 (Oligochaeta, Glossoscolecidae). Bolm Zool. Univ. S. Paulo, 6: $15-46$.

Cordier, R., 1934. Études histophysiologiques sur la nephridie du Lombric. Archs. Biol., 45: 431-71.

Costa, A. C. \& P. R. Chaves, 1943. Manual de técnica histológica. Lisboa, Portugália, $544 \mathrm{p}$.

Dev, B., 1965. The cytochemical localization of alkaline phosphatase in the testicular nephridia of the Indian leech, Hirudinaria granulosa with special reference to the inner lobe. Q. Jl. microsc. Sci., n.s., 106: 351-5.

El Duweini, A. K., 1940. The anatomy of Allolobophora caliginosa (Savigny, f. trapezoides (Dugès). Bull. Fac. Sci. Egypt Univ. Cairo., 21: 59-151.

Goodrich, E. S., 1933. On the nephridiostome of Lumbricus, Q. Jl. microsc. Sci., 75: 165-79.

Goodrich, E. S., 1946. The study of nephridia and genital ducts since 1895 . Q. Jl. microsc. Sci., 86: 113-392.

Gomori, G., 1952. Microscopic histochemistry: principles and practices. Chicago, Univ. Chicago Press. 226 p.

Graszynski, K., 1963. Die Feinstruktur des Nephridialkanals v.on Lumbricus terrestris L., Eine eletronenmikroskopiche Untersuchung. Zool. Beitr., 8(2): 189-296. 
Graszynski, K., 1965. Biochemische und histochemische Untersuchungen an der "Alkalischen Phosphatase" in Nephridium des Regenwurms, Lumbricus terrestris L. Z. vergl. Physiol., 50: 402-4.

Johansen, K. \& A. W. Martin, 1965. Circulation in a giant carthworm Glossoscolex giganteus. I. Contractile processes and pressure gradients in the large blood vessels. I. exp. Biol. 43:333-47.

Koechlin, N., 1970. Etudes citophysiologiques des nephridies thoraciques d'une annélide polichète (Sabelle): I. Bases ultraestructurales de la permeabilité de la paroi des branches montantes, descendantes e des dissépiments. Archs. Anat. microsc. Morph. exp., 59(4): 331-60.

Knop, J., 1926. Bakterien und Bakterioiden bei Oligochäten. Z. Morph. Ökol. Tiere., 6: 588-624.

Langeron, M. Précis de microscopie. 1934. Paris, Masson. 1205 p.

Laverack, M. S., 1963. The physiology of earthworm. New York, Mac Millan, 206 p.

Lison, L., 1960. Histochimie et cytochimie animales. Paris, Gautier-Villars, 2 v.

Ljungstrom, P. O., 1972. Biology of Glossoscolex uruguayensis (Glossoscole. cidae, Oligochaeta). A new species for Argentina. Stud. Neotrop. Fauna., 7: 195-205.

Maziarski, S., 1903. Recherches cytologiques sur les organes segmentaires des vers de terre. Poln. Arch. biol. med. Wiss., 2: 3-83.

McClung, C. E., 1937. Handbook of microscopical technique. New York, Hoeber, 698 p.

McManus, J. F. A. \& J. E. Cason, 1950. Carbohydrate histochemistry studies by acetilation techniques. I. Periodic acid methods. J. exp. Med., 91: 651-654.

Michaelsen, W., 1897. Organization einiger neuer oder wenig bekannter Regenwürmer von Westindien und Südamerika. Zool. Jb. (Anat)., 10: 359-88.

Neder, E. N., 1964. Introdução à microbiologia: Guia de aulas práticas do Curso de Microbiologia Aplicada. Piracicaba. Instituto de Zootecnia "Prof. Jayme Rocha Almeida", ESALQ. 118 p.

Pandazis, G., 1931. Zur Frage der Bakteriensymbiose bei Oligochäten. Zentbl. Bakt. ParasitKde Abt I Orig., 120 (7/8): 440-52.

Pantin, C. F. A., 1964. Notes on microscopical technique for zoologists. Cambridge, Cambridge Univ. Press., 76 p.

Pearse, A. G. E., 1953. Histochemistry: theoretical and applied. London, Churchil, $530 \mathrm{p}$.

Perrier, E., 1874. Études sur l'organization des Lumbricides terrestres (Urochaeta). Archs Zool. exp. gén. 3: 331-530.

Pickford, G. E., 1940. An account of the anatomy of a giant earthworm from Ecuador. Turtox News, 18(17): 1-6.

Policard, A.; M. Bessis \& M. Locquin, 1957. Traité de Microscopie. Paris, Masson. 608 p.

Righi, G., 1971. Sobre a Família Glossoscolecidae (Oligochaeta) no Brasil. Archs zool. Est. S. Paulo, 20(1): 1-95.

Rosen, F., 1911. Wimpertrichter der Lumbriciden (Ein Beitrag zur Kenntnis der lymphoiden Organe). Z. wiss. Zool., 98: 135-78.

Scott, D. A. \& A. J. Musgrave, 1973. Aspects of the fine structure of symbionts and related host tissues in nephridia of Allolobophora caliginosa typica (Annelida: Lumbricidae) J. invertebr. Pathol., 6(5): 515-19.

Stephenson, J., 1930. The Oligochaeta. Oxford, Clarendon Press. 978 p.

Vanderbrock, G., 1934. Organogènese du système nephridien chez Eisenia foetida Sav. Recl. Inst. zool. Torley-Rousseau, 5: 5-72.

Vinichenko, L. N. \& V. K. Lebskii, 1975. Comparative ultraestructural analysis of the protonephridium of Eteone longa and the metanephridium of Lumbricus terrestris. Tsitologiya, 17(6): 615-19.

Zerbst-Borofka, I., 1975. Function and ultrastructure of the nephridium in Hirudo medicinalis L.: III: Mechanisms of the formation of primary and final urine. J. Comp. Physiol. B. Metb. Trans. Funct., 100(4): 307-316. 
ABREVIATURAS

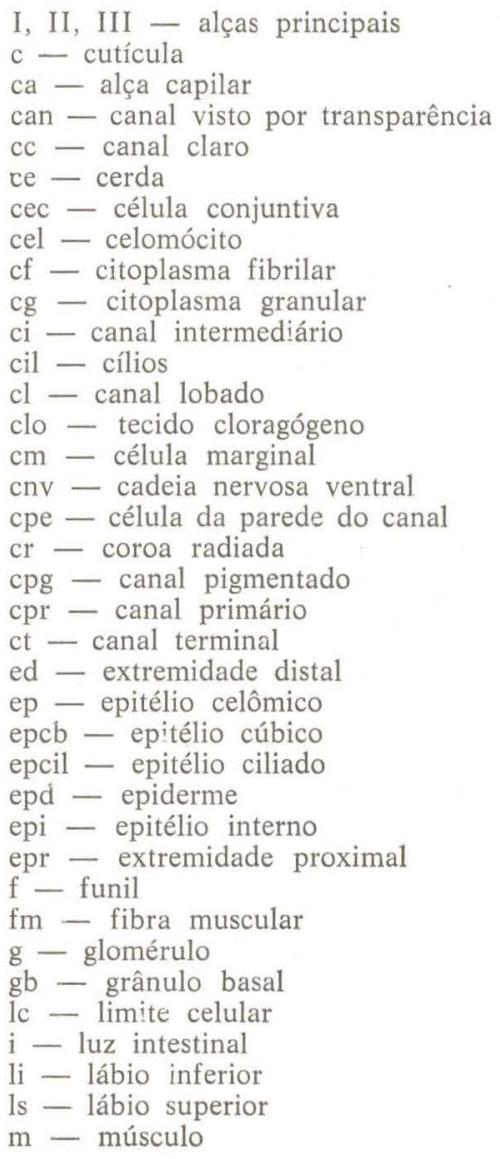

$\mathrm{mb}$ - membrana basal

mi - musculatura intestinal

$\mathrm{mc}$ - musculatura circular parietal

$\mathrm{ml}$ - musculatura longitudinal parietal

ms - músculo da cerda

mu - mucócito

np - nefridióporo

nu - núcleo celular

nue - núcleo de célula epitelial da parede do duto

nuen - núcleo de célula endotelial nup - núcleo de célula peritoneal nurp - núcleo de célula do revestimento pavimentoso do glomérulo

nutc - núcleo de célula conjuntiva

pg - granulação pigmentada

ra I - ramo aferente da alça I

re I - ramo eferente da alça I

$\mathrm{s}$ - septo

sda - ramo aferente do segmento delgado

sde - ramo eferente do segmento delgado

tc - tecido conjuntivo

tci - tubo ciliar

tc I $-10^{\circ}$ segmento contornado

tc II $-2 .^{\circ}$ segmento contornado

$\mathrm{v}$ - vaso sangüíneo

vc - vacúolo

vd - vaso dorsal

ve - vesícula

vef - vaso eferente

vi - vilosidade

vv - vaso ventral 